of the limbs and trunk, or segments of them, are remarkably constant for these populations, and a close approach to equality is also found in variation and correlation. If data for stature, but for no other character, are available for a particular one of the countries, then it is possible to predict a great deal of information regarding other characters of its members by applying results derived from the surveys of other countries. This is a statistical matter, and the scope and accuracy of the predictions referred to could be investigated adequately by treating extensive material available in the anthropological literature.

The population of the British Isles has remained unsurveyed by anthropologists, though records of the statures, at least, of large numbers of men of military age must have been determined in recent years. It is fortunate that extensive anthropometric surveys have been carried out for two allied populations, namely, the Swedish and Norwegian. In fact, these two have been better described in the respect considered than any others in the world. With proper reservations, the results for them could be applied to men from the British Isles to give information required for military purposes. There are several other ways in which knowledge and experience gained by physical anthropologists might be applied immediately to certain military problems in the interests of economy and efficiency. It may not be proper to ask what has been done already in this direction, but there can be no impropriety in suggesting that this is a matter which should be given careful consideration by those responsible for the Government's policy on the use of scientific and technical resources.

The need seems to be for an advisory committee which could deal with all questions of the kind referred to. Such a body should include anthropologists with knowledge of the relevant literature and experience of techniques used in measuring human beings, and statisticians who would ensure that the data were used in the best way. One of their first tasks might be the reduction of body measurements already taken of men serving in the Fighting Forces. Information derived from them should be presented in a concise and convenient form to those requiring it who are concerned with production and the assignment of men to particular duties. The value of published anthropometric records for the same purposes could also be considered, and the committee might seek permission to use the data collected in certain unpublished surveys of sections of the British population which have been carried out for academic purposes. It could be called on to deal with any new problems falling within its scope, and should be given power to undertake new investigations involving the measuring of samples of the populations concerned. The primary aim would be the speedy solution of problems connected with immediate war-time needs; but it is not to be doubted that the information and experience gained would later be found to be of scientific value in elucidating certain problems of medicine and race biology which are also of great importance to the State.

\section{WORLD CO-OPERATION IN PRODUCTION, CONSUMPTION AND DISTRIBUTION}

QIR STAFFORD CRIPPS'S address on July 25 at $\checkmark$ the Conference on Mineral Resources arranged by the Division for the Social and International Relations of Science of the British Association was noteworthy as an indication that the Government is willing and eager to meet the challenge of a remarkable series of speeches recently made by leading American statesmen. The views expressed by $\mathrm{Mr}$. Wallace, Mr. Milo Perkins and Mr. Sumner Welles in May, by Mr. Winant at Durham in June, and by Mr. Claud Wickard, Mr. Dean Acheson and Mr. Appleby in July, all of whom are intimately concerned with the formulation of American policy, may be taken to represent official thought in the United States on the problems of post-war reconstruction. Sir Stafford Cripps, in welcoming these beginnings of an interpretation of the generalities of the Atlantic Charter, was clearly speaking for the Government, and in promising "willing co-operation along the paths which they indicate", he carried a stage further the promise made earlier in the same week by Mr. Eden and Sir William Jowitt.

The keen interest in these pronouncements betokens the general sympathy in Great Britain with the American agreement and the desire that British leaders should take their full share in formulating future policy on these lines. In Great Britain as in the United States, war is seen as part of a continuous process the roots of which lie deep in poverty, insecurity, starvation and unemployment, and this War will not be really won until the deep causes of war have been uprooted. As Mr. Winant says, this is no short-term military job : "To crush fascism at its roots we must crush depression democracy. We must solemnly resolve that in our future order we will not tolerate the economic evils which breed poverty and war. This . . . is part of the war. . . ."

This new thesis, this deeper view of social and international responsibility, which goes down to the foundations of society in seeking to discover the causes of such manifestations of social disease as totalitarian war, is quite incompatible with isolationism, which it would eliminate, not only on the grounds of world solidarity and comradeship but also of plain self interest. It involves a moral revolution which Sir Stafford Cripps did well to emphasize. Warmly as these views are welcomed, it would be a disaster if there were any failure to understand the sacrifices and changes which will be demanded if the principles of the Atlantic Charter are to become more than pious aspirations. The reports of the Chambers of Commerce, the National Union of Manufacturers and the Federation of British Industries, all issued in the same period, are both measure and warning of the opposition, the prejudices and the difficulties which have to be overcome.

It is, of course, only in broad outlines that the solution is sketched in the speeches made by the American statesmen. Mr. Wallace, referring to 
America's opportunity, suggests that the century on which we are entering will be known as the century of the common man. It may be America's oppor. tunity to suggest the freedoms and duties by which the common man must live; and modern science, when devoted wholeheartedly to the general welfare, has in it potentialities of which we do not yet dream. But the will to peace and the continued co-operation of the United States and Britain form the political framework. No nation will have the God-given right to exploit other nations. Older nations will have the privilege of helping younger nations to start on the path to industrialization, but there must be neither military nor economic imperialism, and modern science must be released from German slavery. There can be no privileged peoples, and there will be the supreme duty for the citizen of sacrificing the lesser interest for the greater interest of the general welfare. Moreover, as Mr. Cordell Hull puts it, we must no longer ignore the simple but fundamental fact that the price of peace and of the preservation of right and freedom among the nations is the acceptance of international responsibility.

Mr. Welles, in his address, suggested broadly a long armistice, the disarmament of the aggressors, a United Nations police force, and finally the United Nations as the nucleus of a world organization to determine the final terms of a just, an honest and a durable peace as successive stages. This approach to political and military security springs from that new conception of the deep causes of war and of the new and dynamic conception of post-war relations which finds such vivid expression in Mr. Winant's great speech at Durham. The scientific and economic resources which produce the weapons of war can produce in as great a measure the instruments of peace.

"We have enough technical knowledge and organizing ability to respond to this awakening of social conscience... When war is done the drive for tanks must become a drive for houses. The drive for food to prevent the enemy from starving us must become a drive for food to satisfy the needs of all people in all countries. The drive for physical fitness in the Forces must become a drive for bringing death and sickness rates in the whole population down to the lowest possible level. The drive for man-power in war must become a drive for employment to make freedom from want a living reality. The drive for an all-out war effort by the United Nations must become a drive for an all-out peace effort based on the same co-operation and willingness to sacrifice."

It is not beyond our technical or spiritual capacity, Mr. Winant continued, to have these basic things, and his speech gives noble expression to the expansive, purposeful concept of economics which underlies the new American outlook, the philosophy of what $\mathrm{Mr}$. Sumner Welles calls "the frontier of human welfare". The key is expanding markets, a "mass consumption great enough to use mass production", "a future planned in terms of increase and not curtailment". Within the broad framework, private enterprise and free trade-the progressive sealing down of trade barriers and the end of all discriminating measures- are to be the chief instruments of economic advance, though some measure of Government control is envisaged, and Mr. Milo Perkins speaks of " $a$ bold and daring use of long-term credits by Governments entering fields where private finance cannot enter without taking risks that are too great to take with other people's money".

There can be no doubt as to the revolutionary character of the policy advanced in these speeches. They represent a new conception of world order and an inspiring attempt to reinterpret democracy in terms of the twentieth-century situation and to extend its meaning in the economic and social sphere much as Lord Elton has done in "St. George or the Dragon". But it must be recognized that while this call for a co-operative venture, broadly based on the idea of the United Nations, comes from the progressive elements in the United States, there are powerful interests as well as many individuals who do not accept the thesis of co-operation.

For this reason the speeches of Sir Stafford Cripps, Mr. Eden and Sir William Jowitt were specially welcome. Sir Stafford Cripps rightly emphasized the moral revolution which is required if the principles of the Atlantic Charter are to become more than mere platitudes. Behind our scientifically prepared plans there must be, he urged, the inspiration of our deepest religious convictions. That will carry us along the road on which our feet have already been set in developing the plans of the United Nations for their war effort-the subordination of private and national interests to the public and international good.

The determined change of outlook from that of competition to that of co-operation will be as imperative after the War as for its prosecution, and without that outlook we may fail once again to carry over into the work of building the peace the organization for pooling material and experience developed for winning the War. Much of that may well serve eventually as the foundation of a permanent system of international management, and this series of speeches in Great Britain and in the United States of America should be welcomed first for its contribution to the education of public opinion to the sacrifices in private and sectional and national interests which will be involved. Neither Mr. Eden nor Sir Stafford Cripps failed to indicate the extent to which it is in the hands of the people of both countries how far this great experiment of AngloAmerican co-operation can be continued after the War, and the necessity for a moral basis.

In associating himself with the hopes inspired by the American speeches, Mr. Eden pointed out that the solution of this problem of organizing full pro. duction and equitable distribution of what is produced would demand not only hard work and goodwill but also political invention of a very high order. The new problems cannot be solved along the old lines. In view of the caution and conservation of some of the industrial reports, it is all the more encouraging that Lord Simon, speaking in the House of Lords, should declare that we do not intend to be bound by the orthodoxies of the nineteenth century, 
and he emphasized that passage in President Roosevelt's report to Congress on June 11 on Lend-Lease operations in which the President asserted that the financial costs of the War can and should be met in a way which will serve the needs of lasting peace and mutual economic well-being; he also declared the Government's full agreement with the statement and its conviction that it provides a firm and solid basis for co-operation with the United States in winning the peace. The principles of expanding consumption and rising standards of living are also discussed by Mr. Walter Elliot in a recent thoughtful article in which he elaborates the theme of making them the foundations of an ordered and prosperous international community after the War, starting from the point made by Mr. Milo Perkins that our civilization is commodity-rich and consumption-poor. The interest aroused by the British Association Conference on mineral resources and the Atlantic Charter shows how public opinion in Great Britain is becoming aware of what is involved, and is prepared to support that survey of needs which must follow the research into the extent of world resources, of the methods of making them available and of placing them at the disposal of those who need them.

All this is required as a basis for action, and beyond this question of production there lie the even more baffling problems of distribution and consumption. The recent speech of Mr. Nash, Finance Minister of New Zealand, who had early suggested the creation of a World Reconstruction and Development Council through which a positive programme could be mapped out for carrying on a world of peace, contained a friendly warning which we do well to heed. $\mathrm{He}$ referred to our failure to give full weight to post-war reconstruction and development, which is the major aim of a large and influential section of the American people. Moreover, his concern that the whole management of the national war effort is being seriously handicapped by excessive reluctance to interfere with existing channels of production and trade applies equally to reconstruction.

The discussion on economic reconstruction after the War, opened by Mr. R. G. Glenday before the Royal Statistical Society on March 17, which has now been reported in the Journal of that Society, makes a timely appearance as a corrective to facile optimism which might be engendered by these pronouncements. Mr. Glenday insisted that changes in the business environment must be scientifically analysed and understood before any useful work could be done in planning for post-war reconstruction. He suggested that a factual examination of the condition of Britain's economic environment during the two pre-war decades would show that the change from Free Trade to Pro. tection in 1931 was largely forced upon us by influences outside the individual control of governments. The major factors in precipitating this economic revolution, of which the present War should be regarded as part are, in Mr. Glenday's judgment, the closing of the age of territorial expansion, and the slowing down in the rate of population growth in the more developed and wealthier countries, coupled with continuing expan- sion in the less mature; and the failure to appreciate that, even though an economic system may not be consciously planned, it must in its process of growth conform to certain rules of order and structure if it is to avoid breakdown. In particular, the rates of growth of its separate parts must be kept in proper relation to one another, and for every structure there will be a most convenient size.

Mr. Glenday was clearly somewhat pessimistic as to the ability of industry to continue automatically to provide expanding avenues of employment, but while he pointed out correctly that the problem is that of creating new avenues of employment fast enough to absorb those thrown out of work by technological developments of a labour-saving kind, he appeared, as Prof. A. C. B. Fisher observed, to accept as axiomatic without further question that the obstacles he indicated were irremediable. Mr. Glenday did indeed suggest that the new comradeship of effort brought into being by the War may be the only solid foundation that we shall possess on which to build that new world for which so many are yearning, but his reference to the Atlantic Charter was scarcely constructive. Both Sir William Beveridge and Mr. Stanley Jevons joined issue with Mr. Glenday on these points, as indeed did Sir Gwilyn Gibbon, in whose brief appeal for concrete proposals rather than generalities lie the untold possibilities of further scientific advances. Sir William Beveridge, speaking from the chair, insisted that it is in our power to abolish want and to cure the evil of urban congestion, provided that we win the War and make such a reasonable contribution towards winning it; that the rest of the world would be friendly; that the nation wills these changes sufficiently to override the various vested interests; and that the changes are adequately planned. The transition problems would undoubtedly be harder to deal with at the end of this War, and Sir William urged that we should pay at least as much attention to problems of which the solution is within our power as to those of which the solution requires an international agreement.

There should be a generous response to the wider understanding, the quickened sense of human sympathy, and recognition of the common purpose of humanity which finds expression in both British and American speeches, and men of science will be able, by virtue of their training and outlook, to bring careful scrutiny to bear on the concrete proposals which may be formulated. But if scientific men, who have been brought up in an atmosphere of international co-operative development, can, as Sir Stafford Cripps pointed out, do much by their example and advice to create this new and challenging spirit among the free peoples of the world, there is one contribution they are supremely competent to make. From none better than from those who have devoted themselves to science, to the search for truth, can the free peoples acquire the habit of facing change fearlessly and bringing to the solution of our great problems of production, consumption and distribution that same adventurous spirit and willingness to accept new ideas and new ways by which science has won its triumphs. 